\title{
PENGEMBANGAN MEDIA PEMBELAJARAN AKSARA JAWA INTERAKTIF BERBASIS MULTIMEDIA (Studi Kasus SD Mardi Rahayu 01 Ungaran)
}

\author{
Setiyo Adi Nugroho', Risti Wulandari ${ }^{2}$ \\ ${ }^{1}$ Progdi Komputer Grafis STEKOM Semarang, nugroho@stekom.ac.id \\ Jl. Majapahit605, Semarang, telp/fax : 024-6717201-02, e-mail:nugroho@ @tekom.ac.id \\ ${ }^{2}$ Progdi Desain Grafis STEKOM Semarang \\ Jl. Majapahit605, Semarang, telp/fax : 024-6717201-02, e-mail: ristyw8 @ gmail.com
}

\begin{tabular}{|c|c|}
\hline ARTICLE INFO & ABSTRACT \\
\hline $\begin{array}{l}\text { Article history: } \\
\text { Received } 23 \text { October } 2020 \\
\text { Received in revised form } 29 \text { October } 2020 \\
\text { Accepted } 12 \text { November } 2020 \\
\text { Available online December } 2020\end{array}$ & $\begin{array}{l}\text { SD Mardi Rahayu 01 Ungaran is an elementary } \\
\text { school. The learning process still uses } \\
\text { conventional methods which make students less } \\
\text { enthusiastic in participating in learning and tend } \\
\text { to get bored with the material presented. The } \\
\text { purpose of this research is to develop } \\
\text { interactive Javanese script learning media based } \\
\text { on multimedia. } \\
\text { The development method in this study uses the } \\
\text { Research and Development method. } \\
\text { Multimedia-based interactive Javanese script } \\
\text { learning media is an alternative in the learning } \\
\text { process. Based on the results of the validation, } \\
\text { the learning media got a feasibility percentage } \\
\text { of 92.5\% from internal validator, 90\% from } \\
\text { external validator, and } 81 \% \text { from the results of } \\
\text { user trials, so it can be concluded that the } \\
\text { learning media developed was categorized as } \\
\text { very feasible to use. } \\
\text { Keywords: Learning media, interactive, } \\
\text { multimedia, Javanese script }\end{array}$ \\
\hline
\end{tabular}

\section{Latar Belakang}

Bahasa Jawa merupakan salah satu bahasa daerah yang banyak digunakan oleh masyarakat Indonesia. Di daerah-daerah tertentu, khususnya di Jawa Tengah, bahasa Jawa digunakan sebagai bahasa sehari-hari. Bahasa Jawa merupakan bahasa budi yang mencerminkan tata krama berbahasa bagi pemakainya. Bahasa Jawa memiliki etika bahasa yang baik untuk digunakan dan mencerminkan karateristik adat budaya Indonesia sebagai bangsa Timur. Lunturnya bahasa Jawa membuat kualitas budi pekerti dan tata krama masyarakat di Jawa semakin menurun. Oleh karena itu, dibuatlah kurikulum untuk mempelajari tentang bahasa Jawa. Dalam kurikulum tersebut terdapat satu pokok bahasan yang mempelajari tentang huruf Jawa atau yang sering disebut dengan aksara Jawa. beberapa contoh huruf 
merupakan huruf(aksara) Jawa yang diambil dari "Buku Pinter Kawruh Basa Jawa Pepak"[1]:

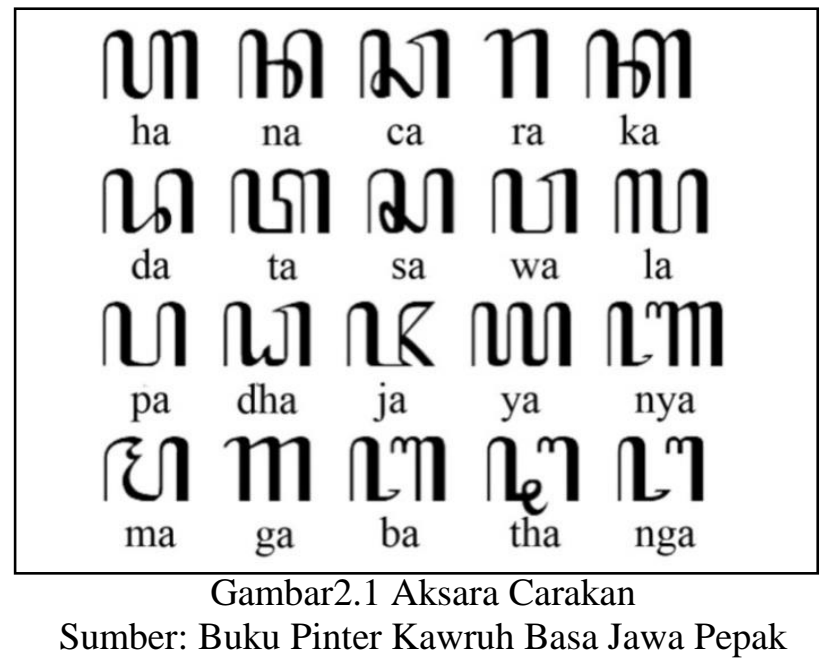

Aksara Jawa atau yang lebih kita kenal dengan Hanacaraka atau Carakan merupakan salah satu warisan leluhur dan kekayaan budaya bangsa Indonesia yang tidak ternilai harganya. Aksara jawa sendiri telah mendapat pengakuan resmi dari Unicode, lembaga di bawah naungan Organisasi Pendidikan, Ilmu Pengetahuan, dan Kebudayaan Perserikatan Bangsa-Bangsa (UNESCO) pada 2 Oktober 2009, bersamaan dengan penetapan batik sebagai warisan budaya tak benda Indonesia. Dengan pengakuan itu, kini Aksara Jawa setara dengan huruf lain di dunia yang telah lebih dulu digunakan untuk program komputer yakni bahasa Latin, China, Arab, dan Jepang. Seiring berjalannya waktu dan kemajuan teknologi yang semakin pesat, menyebabkan warisan budaya seperti aksara Jawa mulai ditinggalkan dan kurang diminati untuk dipelajari, padahal didalamnya memuat berbagai macam nilai luhur. Aksara Jawa kini semakin tidak dikenali oleh masyarakatnya sendiri termasuk generasi muda, karena secara umum masyarakat Indonesia sudah menggunakan bahasa resmi yaitu bahasa Indonesia dan aksara Latin dalam berkomunikasi secara tertulis. Oleh karena itu, pendidikan tentang kebudayaan dan karya sastra Jawa seperti aksara Jawa perlu diajarkan sejak duduk di bangku pendidikan sekolah dasar.

Pembelajaran aksara Jawa di sekolah dasar terintegrasi pada muatan pelajaran Bahasa Jawa, dengan alokasi waktu 2 jam pelajaran per minggu. Alokasi ini sangat kurang, mengingat banyaknya kompetensi yang harus dipelajari oleh siswa. Hal itu menyebabkan siswa kurang memahami materi sehingga berpengaruh pada perolehan nilai. Dalam kegiatan belajar mengajar, guru hanya menggunakan media berupa buku ataupun gambar dinding yang cenderung monoton dan kurang menarik. Hal itu menyebabkan siswa kurang memahami materi dan merasa cepat bosan saat kegiatan belajar mengajar berlangsung. Kegiatan pembelajaran aksara Jawa sebaiknya dilaksanakan dengan lebih variatif agar dapat memotivasi siswa untuk lebih giat belajar. Dibutuhkan adanya metode pembelajaran baru berupa alat peraga atau media pembelajaran interaktif berbasis multimedia. Multimedia interaktif sendiri adalah multimedia yang dilengkapi dengan pengontrol yang dapat dioperasikan oleh pengguna, sehingga pengguna dapat memilih apa yang dikehendaki untuk proses selanjutnya[2]. Kelebihan model pembelajaran interaktif adalah bahwa peserta didik belajar mengajukan pertanyaan, mencoba merumuskan pertanyaan, dan mencoba menemukan jawaban terhadap pertanyaan sendiri dengan melakukan observasi atau pengamatan[3]. Dengan memadukan audio dan visual yang menarik seperti kombinasi antara teks, gambar, suara, musik dan animasi akan membuat siswa semangat dalam mengikuti pelajaran. metode ini akan dengan adanya ini akan menciptakan atensi yaitu menarik dan mengarahkan perhatian siswa untuk berkonsentrasi kepada isi pelajaran yang berkaitan dengan 
makna visual yang ditampilkan atau menyertai teks materi pelajaran atau pelajaran itu merupakan salah satu pelajaran yang tidak disenangi oleh mereka sehingga mereka tidak memperhatikan.[4]

Berdasarkan permasalahan di atas, maka dikembangkan media pembelajaran yang versifat interaktif yaitu terkait dengan komunikasi dua arah/suatu hal bersifat saling melakukan aksi, saling aktif dan saling berhubungan serta mempunyai timbal balik antara satu dengan lainnya [5] Media pembelajaran ini diharapkan mampu menjadi alternatif pembelajaran bagian siswa dan metode pengajaran yang baru bagi guru.

\section{Metode Penelitian}

Model pengembangan dalam penelitian ini menggunakan metode penelitian dan pengembangan atau yang lebih dikenal dengan metode Research and Development (R\&D). Menurut Sugiyono [6] metode penelitian dan pengembangan (R\&D) merupakan metode penelitian yang dipakai untuk menghasilkan produk tertentu, dan menguji kefektifan produk itu. Agar bisa menghasilkan suatu produk tertentu yang dipakai untuk penelitian yang bersifat analisis kebutuhan (digunakan metode survey atau kualitatif) dan untuk menguji keefektifan produk tersebut supaya bisa berfungsi di masyarakat luas, maka diperlukan penelitian guna menguji keektifan produk tersebut (digunakan metode eksperimen).

Sugiyono [6] menyatakan bahwa langkah-langkah dalam penelitian R\&D terdiri atas 10 langkah. Secara skematik langkah- langkah tersebut dapat ditunjukkan seperti pada gambar berikut ini:

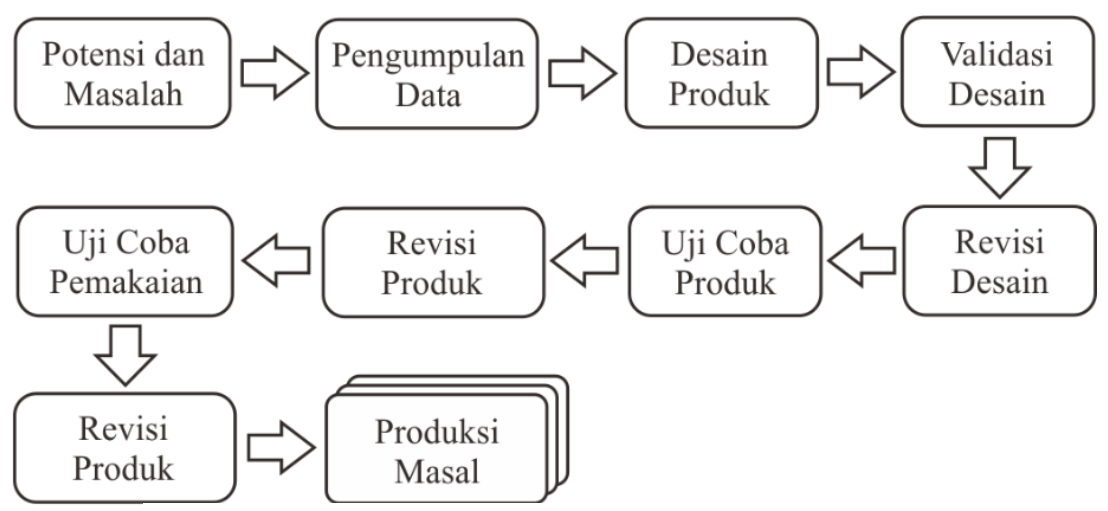

Gambar 1 Skema Metode Research and Development Sumber: Sugiyono [6]

\subsection{Kerangka Berpikir}

Berikut adalah kerangka pemikiran Media Pembelajaran Aksara Jawa Interaktif Berbasis Multimedia di SD Mardi Rahayu 01 Ungaran 


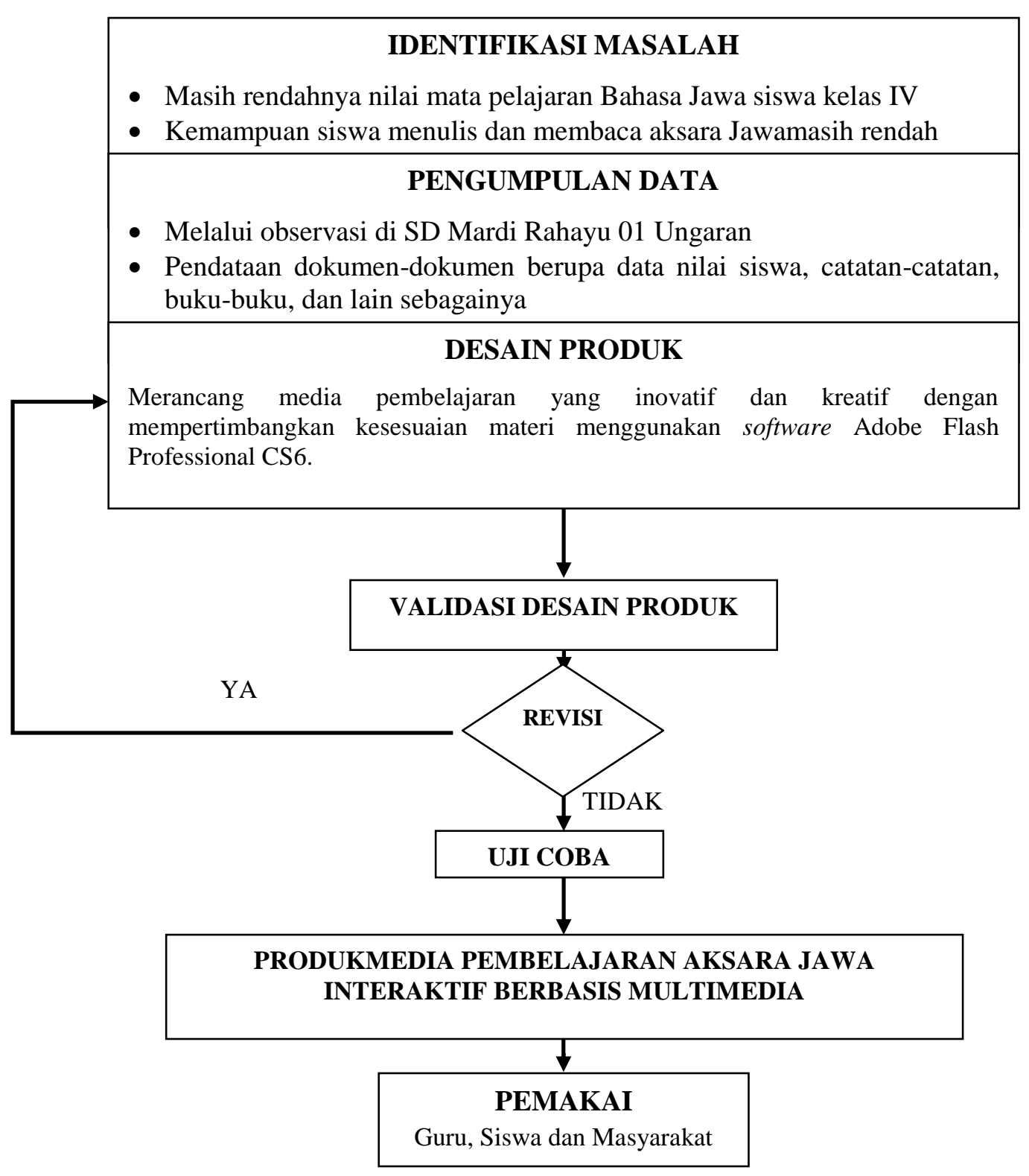

Gambar 2 Kerangka Berpikir

\subsection{Struktur Multimedia}

Struktur kombinasi multimedia sering menggunakan lebih dari satu struktur dalam merancang aliran aplikasi multimedia, yaitu linier, menu, hierarki, dan jaringan [7] dalam penelitian ini rangkaian proses yang terjadi pada media yang dikembangkan adalah sebagai berikut. 


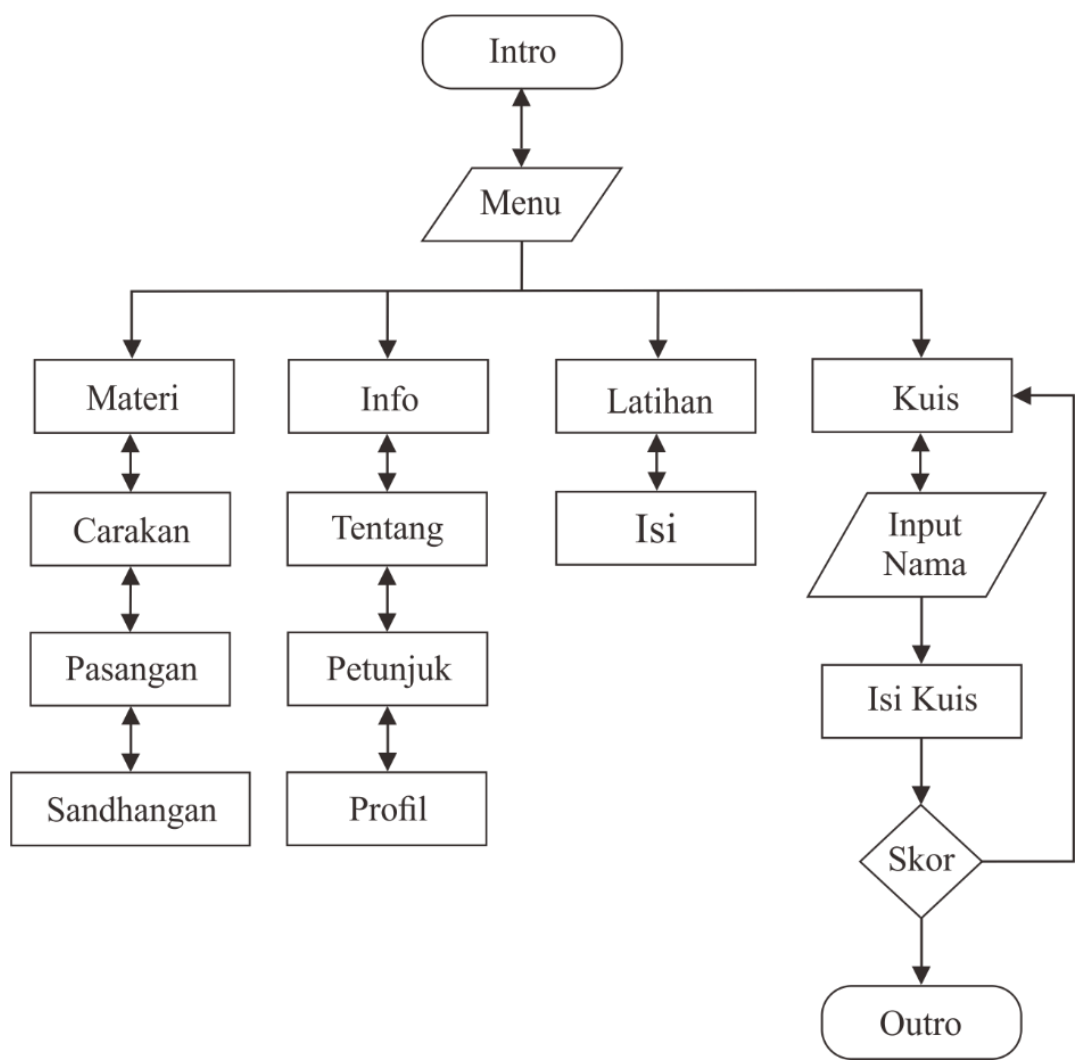

Gambar 3 Sruktur flowchart multimedia

\subsection{Desain Media Pembelajaran}

Pada tahap diterapkan rancangan yang telah disusun. bentuk mutimedia ini adalah Multimedia interaktif offline yaitu media interaktif yang cara penyampaiannya tidak melalui jalur/kawat/saluran/jaringan. Contohnya adalah CD interaktif Company Profile, media pembelajaran, dan lain sebagainya. Media ini termasuk media lini bawah, karena sasarannya tidak terlalu luas dan hanya mencakup masyarakat tertentu saja. [8]

Berikut adalah desain media pembelajaran yang telah dibuat: 
Tabel 1. Desain Media Pembelajaran

\begin{tabular}{|c|l|}
\hline No & \multicolumn{1}{|c|}{ Keterangan } \\
\hline 1
\end{tabular}




\begin{tabular}{|l|l|l|}
\hline 3 & $\begin{array}{l}\text { Berisikan pilihan materi aksara } \\
\text { Jawa seperti aksara carakan, } \\
\text { pasangan, dan sandhangan. } \\
\text { Pilihan materi difungsikan } \\
\text { sebagai tombol, bila diklik akan } \\
\text { menuju ke halaman sub materi } \\
\text { yang dipilih. }\end{array}$ \\
\hline 4 & $\begin{array}{l}\text { Audio: cublak-cublak suweng, lir- } \\
\text { ilir, rek ayo rek, padang bulan, } \\
\text { suwe ora jamu, dondong opo } \\
\text { salak Materi }\end{array}$
\end{tabular}




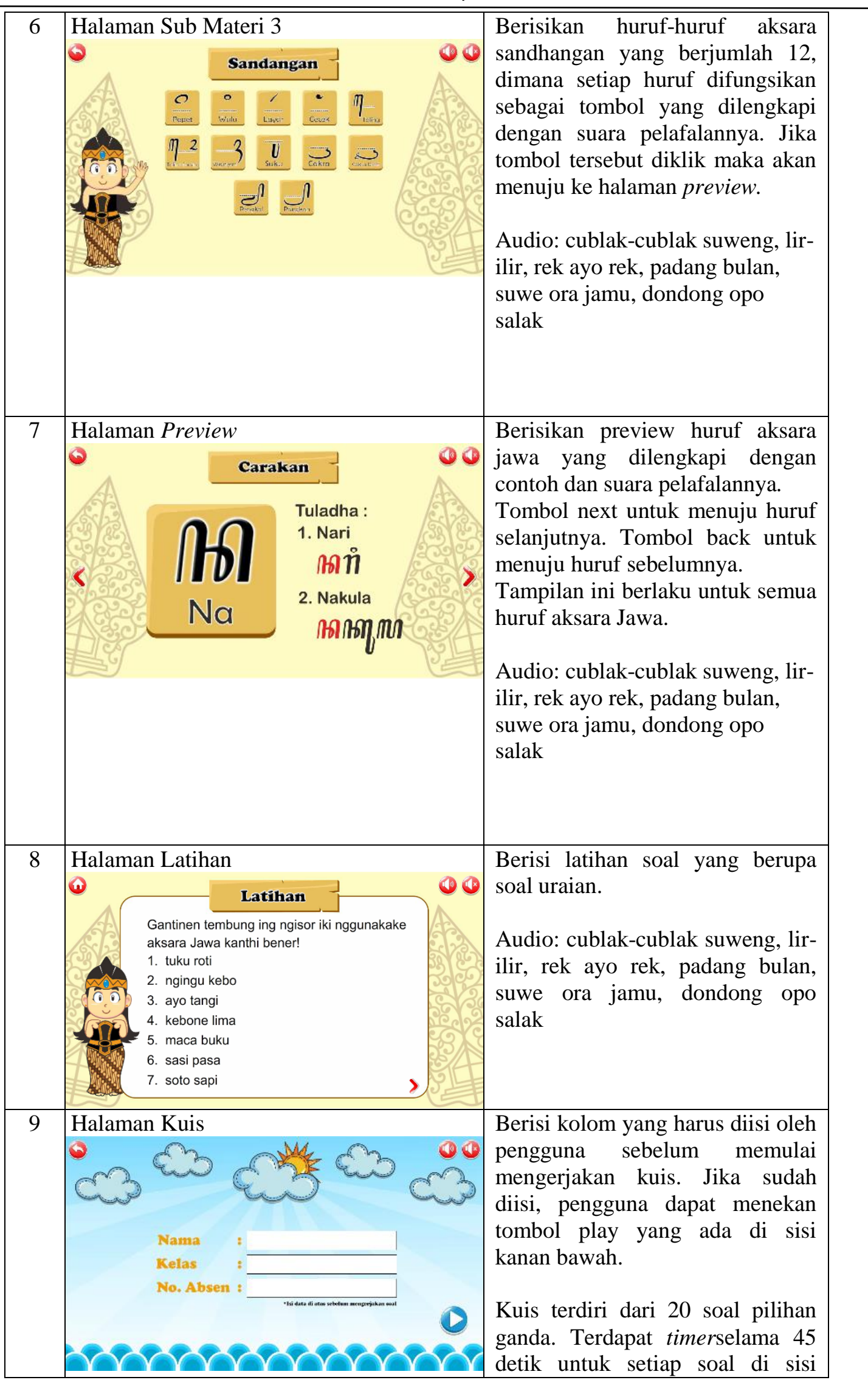




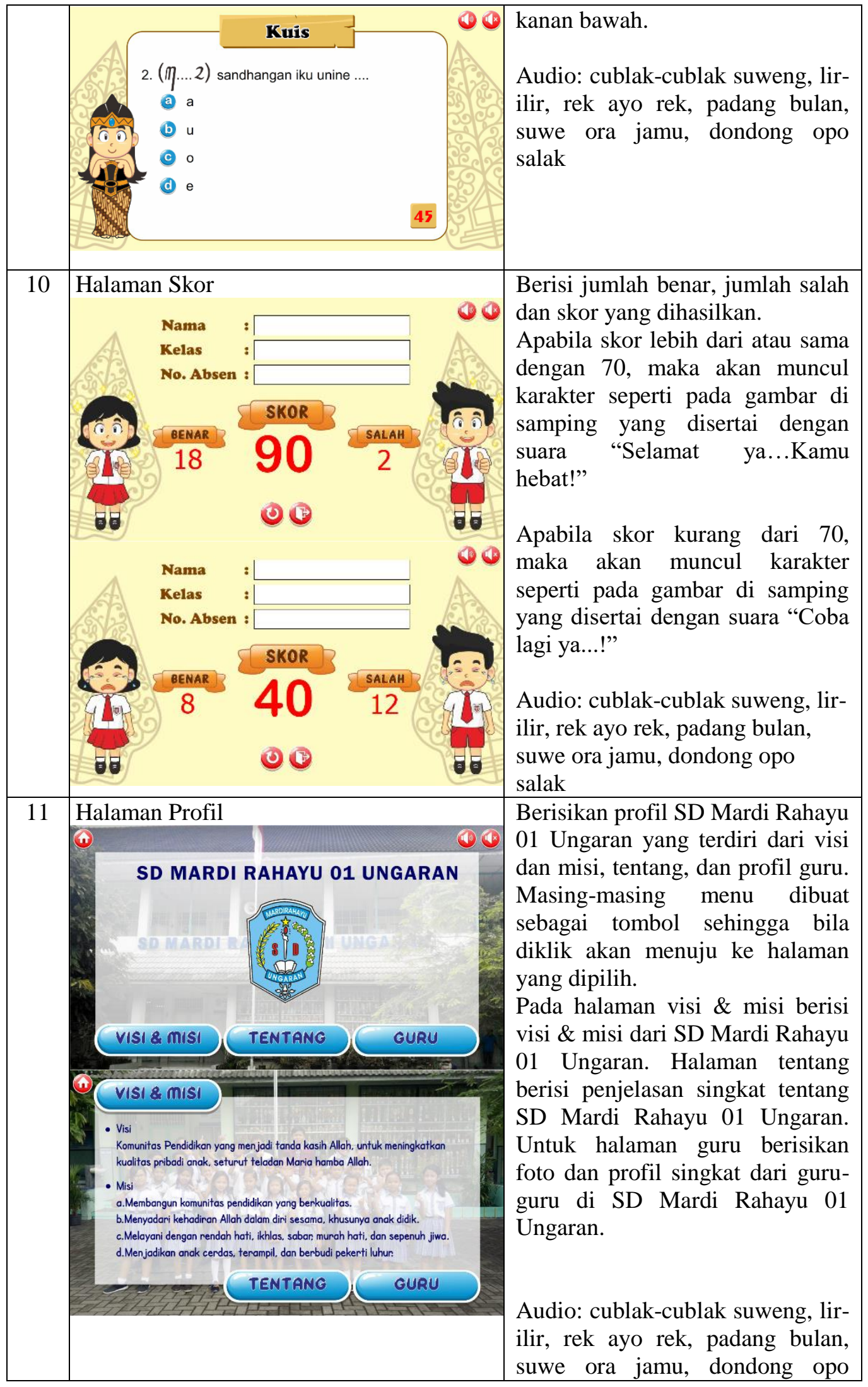




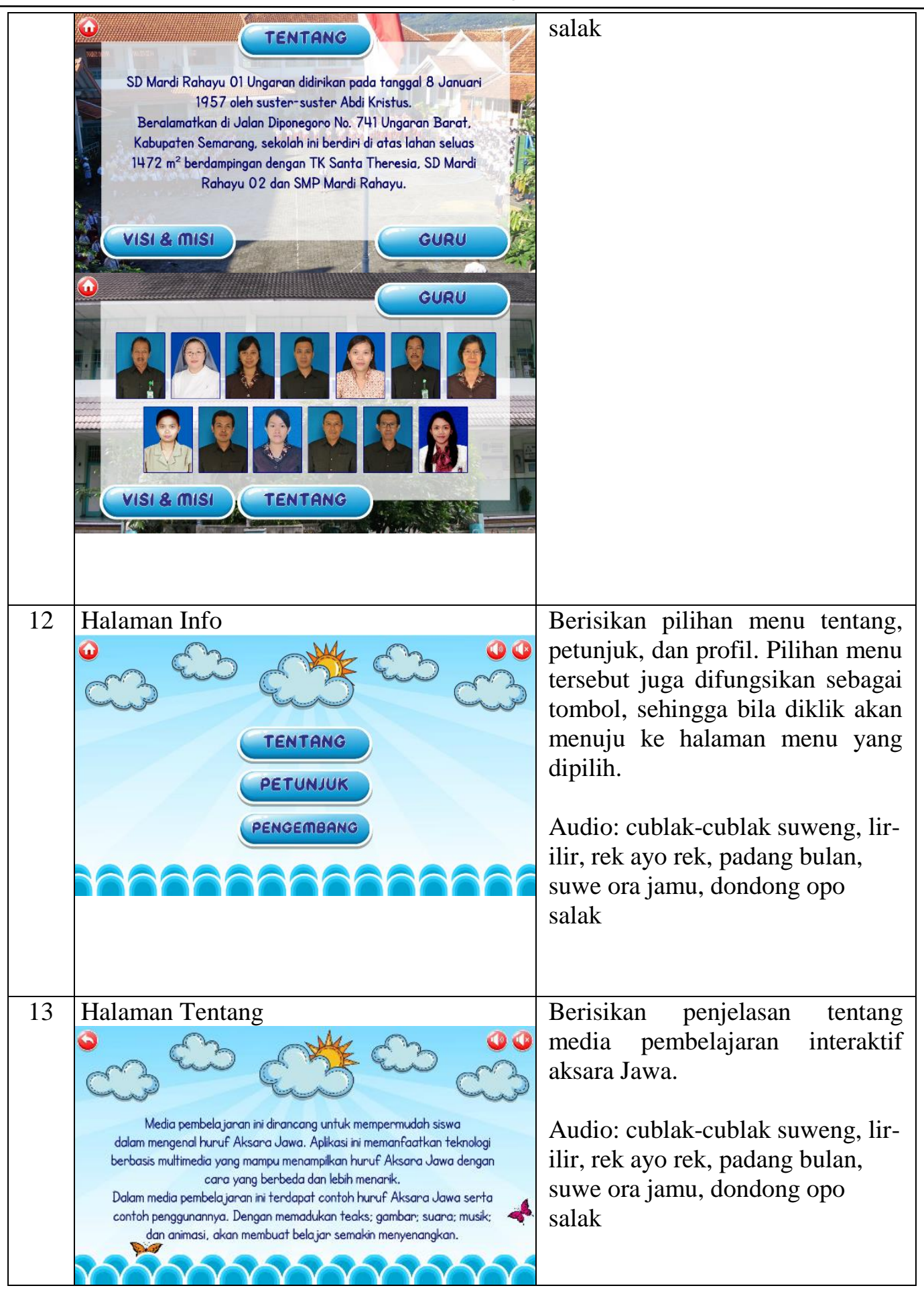




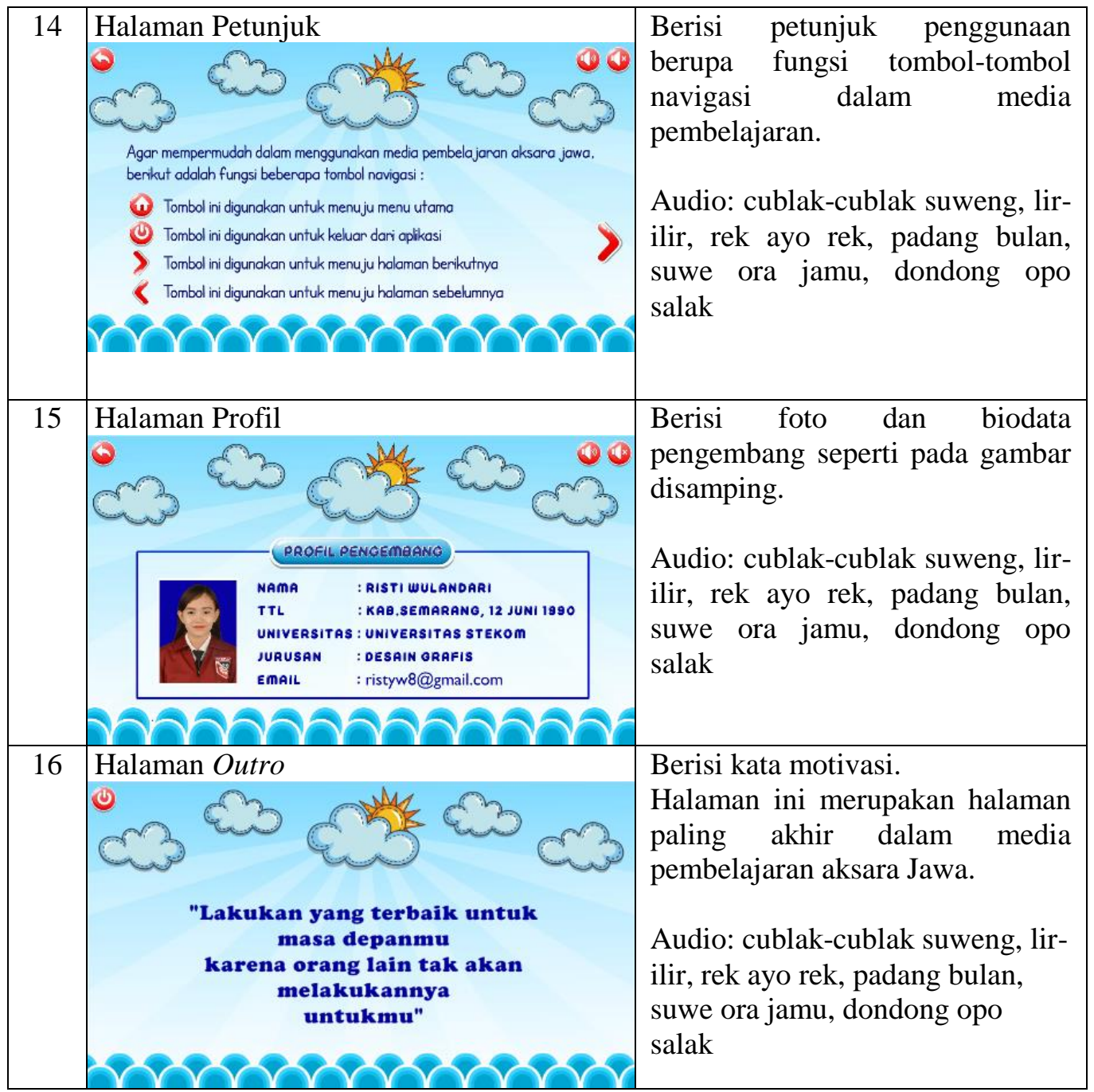

\section{Hasil dan Pembahasan}

Setelah produk selesai diwujudkan, dilakukan tahap pengujian. Pengujian adalah tahap dimana desain produk akan melalui tahap validasi oleh para ahli dan uji cobapenggunauntuk mengetahui apakan produk dapat diterapkan pada kelas. Uji kelayakan diukur berdasarkan penilaian/ validasi dari ahli media, ahli materi, dan pengguna. Dalam penelitian ini jawaban dari pernyataan yang diberikan diklasifikasikan menjadi 4 pilihan. Setiap indikator yang diukur diberikan skala penilaian $1-4$, yaitu:

4 = sangat baik/ sangat jelas/ sangat setuju

$3=$ baik/ jelas/ setuju

$2=$ kurang baik/ kurang jelas/ kurang setuju

1 = sangat kurang baik/ sangat kurang jelas/ sangat kurang setuju

Setelah skor diperoleh, maka dapat menghitung presentasi hasil dengan rumus:

$$
\text { Hasil }=\frac{\text { total skor yang diperoleh }}{\text { skor maksimum }} \times 100 \%
$$

Untuk mengetahui kelayakan media pembelajaran dapat dilihat pada tabel berikut: 
Tabel 2 Kriteria Kelayakan Media Pembelajaran

\begin{tabular}{|c|c|}
\hline Presentase Pencapaian & Interpretasi \\
\hline$<25 \%$ & Sangat Tidak Layak \\
\hline $25-50 \%$ & Tidak Layak \\
\hline $51-75 \%$ & Layak \\
\hline $76-100 \%$ & Sangat Layak \\
\hline
\end{tabular}

\subsection{Hasil Validasi Internal}

Uji validasi ini dilakukan untuk mengetahui pendapat ahli media terhadap kelayakan media pembelajaran yang dikembangkan. Pendapat, kritik, dan saran yang disampaikan oleh ahli media digunakan untuk memperbaiki dan meningkatkan kualitas media pembelajaran. Hasil pengujian dari ahli media dapat dilihat pada tabel berikut:

Tabel 3 Angket Uji Validasi Ahli Media

\begin{tabular}{|c|l|c|c|c|c|}
\hline \multirow{2}{*}{ No } & \multicolumn{1}{|c|}{ Indikator } & \multicolumn{3}{|c|}{ Skala Penilaian } \\
\hline & & $\mathbf{1}$ & $\mathbf{2}$ & $\mathbf{3}$ & $\mathbf{4}$ \\
\hline 1 & Kemudahan pengoperasian & & & & $\checkmark$ \\
\hline 2 & Keterbacaan tulisan (teks) & & & & $\checkmark$ \\
\hline 3 & Ketepatan pemilihan warna & & & $\checkmark$ & \\
\hline 4 & Ketepatan pemilihan musik/ backsound & & & $\checkmark$ & \\
\hline 5 & Tata letak (layout) sudah konsisten & & & $\checkmark$ & \\
\hline 6 & Tampilan desain media pembelajaran menarik & & & & \\
\hline 7 & $\begin{array}{l}\text { Tampilan gambar pendukung tidak mengganggu } \\
\text { keterbacaan teks }\end{array}$ & & & & $\checkmark$ \\
\hline 8 & Tombol navigasi berfungsi dengan baik & & & & $\checkmark$ \\
\hline 9 & Penggunaan tombol sesuai dengan fungsinya & & & & $\checkmark$ \\
\hline 10 & Keseluruhan program berjalan dengan baik & & & & $\checkmark$ \\
\hline \multicolumn{2}{|c|}{ JUMLAH } & & & $\mathbf{9}$ & $\mathbf{2 8}$ \\
\hline \multicolumn{2}{|c|}{ TOTAL NILAI } & & & $\mathbf{3 7}$ \\
\hline
\end{tabular}

Berdasarkan tabel di atas total nilai yang diperoleh adalah 34, sehingga dapat dihitung presentasi nilai validasinya:

$$
\begin{aligned}
\text { Hasil } & =\frac{\text { total skor yang diperoleh }}{\text { skor maksimum }} \times 100 \% \\
& =\frac{37}{40} \times 100 \% \\
& =92,5 \%
\end{aligned}
$$

Dari hasil penghitungan di atas, diketahui bahwa hasil presentase nilai validasinya adalah $92,5 \%$. Nilai ini berada pada skala $76-100 \%$ sehingga dapat disimpulkan bahwa media pembelajaran aksara Jawa interaktif berbasis multimedia dikategorikan sangat layak untuk digunakan. 


\subsection{Hasil Validasi External}

Uji validasi ini dilakukan untuk mengetahui pendapat yang menguasai materi pembelajaran dalam hal ini adalah guru kelas IV SD Mardi Rahayu 01 Ungaran terhadap kelayakan media pembelajaran yang dikembangkan. Pendapat, kritik, dan saran yang disampaikan oleh ahli materi digunakan untuk memperbaiki dan meningkatkan kualitas media pembelajaran. Hasil pengujian dari ahli materi dapat dilihat pada tabel berikut:

Tabel 4 Angket Uji Validasi Ahli Materi

\begin{tabular}{|c|c|c|c|c|c|}
\hline \multirow{2}{*}{ No } & \multirow{2}{*}{ Indikator } & \multicolumn{4}{|c|}{ Skala Penilaian } \\
\hline & & 1 & 2 & 3 & 4 \\
\hline 1 & Materi sesuai dengan kebutuhan siswa & & & & $\checkmark$ \\
\hline 2 & Kelengkapan materi yang disajikan & & & & $\checkmark$ \\
\hline 3 & Kejelasan materi/ konsep & & & & $\checkmark$ \\
\hline 4 & Kemudahan pengoperasian & & & $\checkmark$ & \\
\hline 5 & Tulisan terbaca dengan jelas & & & & $\checkmark$ \\
\hline 6 & $\begin{array}{l}\text { Ketepatan pemilihan gambar untuk menjelaskan } \\
\text { materi }\end{array}$ & & & $\checkmark$ & \\
\hline 7 & Ketepatan pemilihan musik/ backsound & & & & $\checkmark$ \\
\hline 8 & Kejelasan petunjuk penggunaan & & & $\checkmark$ & \\
\hline 9 & Kesesuaian tema dengan judul & & & $\checkmark$ & \\
\hline 10 & Kesesuaian soal dengan materi & & & & $\checkmark$ \\
\hline & NILAI & & & 12 & 24 \\
\hline & TOTAL NILAI & & & & 36 \\
\hline
\end{tabular}

Berdasarkan tabel di atas total nilai yang diperoleh adalah 36, sehingga dapat dihitung presentase nilai validasinya:

$$
\begin{aligned}
\text { Hasil } & =\frac{\text { total skor yang diperoleh }}{\text { skor maksimum }} \times 100 \% \\
& =\frac{36}{40} \times 100 \% \\
& =90 \%
\end{aligned}
$$

Dari hasil penghitungan di atas, diketahui bahwa hasil presentase nilai validasinya adalah $90 \%$. Nilai ini berada pada skala $76-100 \%$ sehingga dapat disimpulkan bahwa media pembelajaran aksara Jawa interaktif berbasis multimedia dikategorikan sangat layak untuk digunakan.

\subsection{Hasil Validasi Pengguna}

Uji validasi ini dilakukan dalam uji coba kelompok kecil yang terdiri dari 5 responden yaitu siswa kelas IV SD Mardi Rahayu 01 Ungaran. Pengguna diminta untuk merespon 10 pernyataan berikut:

Tabel 4.7 Angket Uji Validasi Pengguna

\begin{tabular}{|l|l|c|}
\hline No & Pernvataan & Skala Penilaian \\
\hline
\end{tabular}




\begin{tabular}{|c|c|c|c|c|c|}
\hline & & 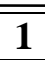 & 2 & $\overline{3}$ & 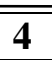 \\
\hline 1 & Media pembelajaran mudah digunakan & & & & \\
\hline 2 & Tampilan media pembelajaran menarik & & & & \\
\hline 3 & $\begin{array}{l}\text { Materi yang ditampilkan sudah lengkap dan } \\
\text { jelas }\end{array}$ & & & & \\
\hline 4 & $\begin{array}{l}\text { Media pembelajaran ini membantu saya untuk } \\
\text { belajar secara mandiri }\end{array}$ & & & & \\
\hline 5 & $\begin{array}{l}\text { Dengan media pembelajaran, belajar aksara } \\
\text { Jawa menjadi lebih menyenangkan }\end{array}$ & & & & \\
\hline 6 & $\begin{array}{l}\text { Gambar dan animasi yang terdapat dalam media } \\
\text { pembelajaran membuat saya lebih termotivasi } \\
\text { untuk belajar aksara Jawa }\end{array}$ & & & & \\
\hline 7 & $\begin{array}{l}\text { Penggunaan musik dalam media pembelajaran } \\
\text { membuat saya lebih bersemangat dalam belajar }\end{array}$ & & & & \\
\hline 8 & $\begin{array}{l}\text { Pembelajaran dengan media pembelajaran ini } \\
\text { sesuai dengan pembelajaran yang saya inginkan }\end{array}$ & & & & \\
\hline 9 & $\begin{array}{l}\text { Dengan media pembelajaran ini saya menjadi } \\
\text { lebih mudah memahami materi }\end{array}$ & & & & \\
\hline 10 & $\begin{array}{l}\text { Belajar dengan media pembelajaran aksara Jawa } \\
\text { interaktif lebih menarik dibandingkan belajar } \\
\text { hanya dengan buku paket saja }\end{array}$ & & & & \\
\hline
\end{tabular}

Berdasarkan data dari 5 responden dengan 10 pernyataan di atas, diperoleh hasil sebagai berikut:

Tabel 4.8 Hasil Uji Coba Pengguna

\begin{tabular}{|c|c|c|c|c|c|}
\hline \multirow{2}{*}{ Responden } & \multicolumn{4}{|c|}{ Skala Penilaian } & \multirow[b]{2}{*}{ Jumlah } \\
\hline & $\mathbf{1}$ & 2 & 3 & 4 & \\
\hline 1 & 0 & 0 & 0 & 40 & 40 \\
\hline 2 & 0 & 2 & 12 & 20 & 34 \\
\hline$\frac{2}{3}$ & 0 & 0 & 0 & 40 & $\frac{7}{40}$ \\
\hline 4 & 0 & 0 & 9 & 28 & 37 \\
\hline 5 & 0 & 0 & 18 & 16 & 34 \\
\hline \multicolumn{5}{|c|}{ Total } & 185 \\
\hline
\end{tabular}

Berdasarkan tabel di atas total nilai yang diperoleh adalah 158, sehingga dapat dihitung presentase nilai validasinya:

$$
\begin{aligned}
Y & =\text { skor tertinggi likert } x \text { jumlah responden } \\
& =40 \times 5 \\
& =200
\end{aligned}
$$

$$
\begin{aligned}
\text { Hasil } & =\frac{\text { total skor }}{Y} \times 100 \\
& =\frac{185}{200} \times 100 \% \\
& =92,5 \%
\end{aligned}
$$

Dari hasil penghitungan di atas, diketahui bahwa hasil presentase nilai validasinya adalah $92,5 \%$. Nilai ini berada pada skala presentase $76-100 \%$ sehingga dapat disimpulkan bahwa media pembelajaran aksara Jawa interaktif berbasis multimedia 
dikategorikan sangat layak untuk digunakan oleh siswa kelas IV SD Mardi Rahayu 01 Ungaran.

\section{Kesimpulan}

Berdasarkan hasil yang diperoleh selama pelaksanaan penelitian dan pengembangan media pembelajaran dapat disimpulkan bahwa:

1. Media pembelajaran aksara Jawa interaktif berbasis multimedia merupakan salah satu alternatif dalam kegiatan belajar mengajar bagi guru dan siswa kelas IVSD Mardi Rahayu 01 Ungaran. Dengan adanya media pembelajaran interaktif, proses pembelajaran menjadi lebih menarik dan menyenangkan sehingga akan menambah semangat dan motivasi siswa dalam belajar.

2. Terciptanya media pembelajaran baru yang memanfaatkan teknologi multimedia, sehingga kegiatan pembelajaran tidak lagi monoton dengan hanya menggunakan buku paket dan gambar dinding saja. Pengembangan media pembelajaran disesuaikan dengan karateristik siswa kelas IV yang cenderung menyukai warna-warna cerah dan gambargambar karakter. Media pembelajaran dibuat dengan tampilan semenarik mungkin dan dilengkapi dengan teks, gambar karakter, audio, animasi serta latar belakang musikyang bertemakan lagu daerah. Dengan media pembelajaran ini siswa tidak hanya belajar tentang aksara Jawaakan tetapi dapat mengenal lagu-lagu daerah juga.

3. Adanya media pembelajaran aksara Jawa interaktif dapat membantu sekolah dalam menerapkan sistem pembelajaran Kurikulum 2013. Siswa menjadi lebih aktif dan mandiri dalam belajar. Pembelajaran yang berbeda dan menarik membuat siswa ikut terlibat secara langsung dalam kegiatan belajar mengajar dibandingkan dengan pembelajaran secara konvensional yang membuat siswa cenderung pasif. Siswa tidak hanya mendengarkan penjelasan dari guru saja tetapi siswa ikut berperan serta dalam memecahkan suatu masalah yang dihadapi saat proses pembelajaran.Kualitas belajar siswa dapat ditingkatkan serta proses pembelajaran dapat dilakukan di mana dan kapan saja tanpa harus didampingi oleh guru.

4. Media pembelajaran ini telah melalui uji validasi dari ahli media, ahli materi, dan uji coba pengguna. Berdasarkan uji validasi dari ahli media didapatkan hasil presentase kelayakan sebesar 92,5\%, dari ahli materi didapatkan presentase kelayakan sebesar 90\% dan dari hasil uji coba pengguna didapatkan presentase sebesar $81 \%$, sehingga dapat disimpulkan bahwa media pembelajaran aksara Jawa interaktif sangat layak untuk digunakan.

\section{Daftar Pustaka}

[1] Angger Maulana F. Abi Tofani. Buku Pinter Kawruh Basa Jawa Pepak. surabaya .Nidyapustaka. 2013

[2] Munir. Multimedia : Konsep dan Aplikasi Dalam Pendidikan. Bandung : Alfabeta. 2012,

[3] Majid, Abdul.Strategi Pembelajaran, Bandung : PT. Remaja Rosdakarya.2014.

[4] Arsyad, Azhar.Media Pembelajaran, Jakarta : PT. Raja Grafindo Persada. 2010. 
[5] Warsita, Bambang.Teknologi Pembelajaran : Landasan dan Aplikasinya, Jakarta. Rineka. 2008.

[6] Sugiyono.Metode Penelitian Kuantitatif, Kualitatif, dan R\&D. Bandung : Alfabeta. 2017.

[7] Nugroho dan Sopyan. Perancangan Media Pembelajaran Berbasis Multimedia untuk Dasardasar Pembuatan Animasi 2D Menggunakan Macromedia Flash MX 2004. Yogyakarta.2011.

[8] Periangan, Benardo.Perancangan Media Interaktif Belajar Mengenal angka Bagi Anak Prasekolah. Bandung. Universitas Komputer Indonesia.2011. 